\title{
Work in Progress: Twenty-five Years of the Convention on the Rights of the Child - The General Measures of Implementation Across the Globe
}

Tara Collins, Ryerson University, and Lisa Wolff, UNICEF Canada

\begin{abstract}
Since its adoption twenty-five years ago, the Convention on the Rights of the Child (CRC) has guided many actors and institutions around the world in relation to children. An important measure of its impact is the status of the general measures of implementation of the CRC, which the UN Committee on the Rights of the Child has identified as a foundational requirement for states to be able to protect, promote and fulfil children's rights. Focusing on law reform, budgeting, monitoring, and independent human rights institutions, this paper describes the state of these general measures with examples from different countries around the world to confirm the CRC's significance in governance and public policy. It is submitted that the CRC has been influential in public policy but that there is much more room for progress guided by the CRC. The paper concludes with recommendations for CRC states parties.
\end{abstract}

Key words: CRC, general measures of implementation, law reform, budgeting, monitoring, independent human rights institutions

\section{Introduction}

The 1989 United Nations (UN) Convention on the Rights of the Child (CRC) is the most successful international human rights treaty ever with 194 states parties (UN, 2014). For 25 years, the $\mathrm{CRC}$ has guided many actors and institutions around the world in relation to children and it continues to be a significant framework for decisions and actions affecting children. 
An important measure of impact is the status of the CRC's general measures of implementation. These general measures comprise: law reform and jurisprudence; budgeting; national plans of action; monitoring processes and mechanisms; education, awareness and training with respect to children's rights; independent national human rights institutions; coordination efforts and mechanisms; participation of civil society in CRC implementation; international cooperation; and ratification and implementation of other relevant international standards (UNICEF, 2005). The UN Committee on the Rights of the Child (hereinafter UN Committee) has identified these general measures as the foundation upon which to ground laws, policies and other actions affecting children (UN Committee, 2003b). Given that children constitute the most vulnerable group in society, comprise a large proportion of the population, yet have few means to influence governments making decisions affecting them, the general measures are designed to ensure that government decisions and actions consider the needs and interests of children. Consequently, in 1996 the UN Committee started requesting information about the status of these general measures in periodic reviews of States parties. Moreover, as governments are the primary duty bearers for children's rights under the Convention, the extent to which a country has put in place the general measures provides an important indicator of political will and capacity to uphold children's rights and support children in society. Studies of CRC progress (UNICEF, 2005; Pearson \& Collins, 2009) emphasize the necessity of bolstering these measures for the full realization of all CRC rights (UNICEF, 2007b; Collins and Wolff, 2012).

The general measures outline the requirements of a "governance architecture" for children's rights that should be established and upheld in a country within every order or level of government (UNICEF Canada 2010). As the UN Committee (2002 and 2003b) elaborated in its General Comments 2, 5 and 14, these general measures outline the mechanisms and procedures for governments as well as other authorities and institutions to facilitate the awareness and political and economic commitment necessary to realize children's rights (UNICEF Canada 2010). Yet CRC implementation has been less effective than anticipated over the past two decades, as Thomas Hammarberg (2009) explains, mainly due to inadequate development of a systematic, comprehensive approach to implementing children's rights as matters of governance and accountability. Some countries have progressed further than others to embed the general measures in their governance structures. What has become evident is that each general measure 
helps strengthen the others, just as each right in the Convention is dependent on the realization of the others. As a result, some children in states that have made less progress in putting in place the general measures do not enjoy the same protections and provisions of their rights as others and many of these disparities go un-remedied. As this paper explores, governments must create and maintain a governance architecture to support the realization of children's rights; they cannot be left to ad hoc action.

The article begins by reflecting on various considerations related to the CRC general measures. This section is followed by a discussion that focuses on the specific general measures of law reform, budgeting, monitoring, and independent human rights institutions with illustrative examples from different countries around the world to confirm the CRC's significance in governance and public policy. ${ }^{1}$ The article concludes with proposed recommendations for improved implementation of CRC general measures as the foundation for a more vigorous promotion of children's rights. While other actors contribute to the implementation and monitoring of children's rights (Collins, 2007), this paper focuses attention on the efforts of the UN Committee on the Rights of the Child, identified as the "UN Committee" throughout.

\section{The General Measures of Implementation}

The category of "general measures of implementation" can transform governance for children in states parties. The UN Committee (1991 \& 1996) identified the category which includes CRC Articles 4, 42 and 44 (6) for CRC reporting. The requirements of these provisions have since been elaborated to reflect a number of implementation obligations at the state level (identified in the introduction). Mindful of the indivisibility and interdependence of all the rights in the CRC, these articles must also be implemented in relation to all other provisions. Thus, CRC states parties, represented by their governments, become legally obligated to implement children's rights through their constitutions, legislation and policies, institutions, programmes and courts as well as to monitor progress. Respect and implementation of children's rights can evolve and transform the aforementioned governance architecture, which determines how governance works for children and ultimately the extent to which children experience their rights. 
The various general measures of implementation are influenced by several obligations and principles including rights-based principles of accountability, progressive realization, cultural relativism and legal pluralism. These principles are discussed briefly below.

In contrast to a needs-based approach, a rights-based approach involves efforts that not only respond to human needs but also reflect obligations to realize children's rights and remedy situations where they are violated (Collins and Wolff, 2012). Rights are a necessary concept because a child may be "invisible" due to her/his legal and social status, according to Boyden, for reasons such as institutionalisation, migration, fear, or monitoring procedures that focus on the household rather than its individual members (as cited in Black 1994, 26-27). A rights-based approach improves the visibility of children to actors beyond the private sphere and may raise the priority given to children by governments.

Two principal motivations generally support rights-based approaches: the intrinsic rationale reflecting the moral and/or legal correctness of an effort, and the instrumental rationale supporting efforts that achieve more effective and improved outcomes (Office of the High Commissioner for Human Rights, 2006). The argument for establishing the general measures of the CRC flows from both, but relies more on the intrinsic rationale given the limited availability of evaluative evidence to demonstrate the link to outcomes for children. To this end, governments accept a dutytocreate and maintain governance mechanisms and promote rights (UNICEF, 2007a). A needs-based approach simply lacks these elements or incorporates them inconsistently through happenstance. A rights-based approach is also concerned with the principles of equity/equality (i.e., actively ensuring non-discrimination and universality; reducing the disparity gaps among children) and interdependence (i.e., recognizing the indivisibility and interdependence of rights; addressing children holistically and coordinating across sectors) (UNICEF, 2007a). For the CRC in particular, a rights-based approach also includes the principles of affording children priority consideration among other groups, taking into account their views in matters affecting them, and doing the utmost to invest in children and achieve optimal outcomes. Rights-based approaches to governance and accountability incorporate mechanisms to activate these principles. 
Accountability of states for child rights implementation is critical to ensuring progress. In addition to being accountable to the international community through political and legal processes, Alston and Tobin (2005, 33-34) explain that the "ideal form" is a "circle of accountability in which governments are accountable to their own citizens for their performance in upholding and promoting human rights." Although children's CRC rights are international standards, both implementation and accountability are sought principally and primarily within a domestic setting. To this end, a rights-based approach to accountability supports the development of legislation, policies, budgets and mechanisms that: identify what rights are to be addressed and who is accountable for these rights; ensure adequate resources are available; and empower people and organizations to support these efforts (Office of the High Commissioner for Human Rights, 2006). The goal of a rights-based approach to accountability can be fulfilled through full implementation of the CRC general measures.

Implementation of child rights is progressive and, necessarily, an ongoing process over time for every state party. As former UN High Commissioner for Human Rights Ayala-Lasso (United Nations, 1996) enunciated, no matter the country, "there is always room to improve current situations [of human rights]." This concept of progressive realization of rights is also reflected in CRC Article 4, and is understood by treaty bodies to mean expeditious and effective progress (UNICEF, 2007a). Continuous progress in CRC implementation is both expected and required. States parties are held accountable to their commitments and the need for progress through regular international monitoring by the UN Committee in accordance with CRC Article 44(1).

Children's rights can be defined to mean different things, posing a challenge to consistent implementation. Cultural relativism is a common challenge to universalism in the human rights discourse, and the argument of "cultural difference" has often been used before the UN Committee on the Rights of the Child (Harris-Short, 2003). However, such stark positioning of either/or in this debate is not helpful in human rights. Consequently, according to expert Philip Alston (1994, 2), monitoring should "involve neither the embrace of an artificial and sterile universalism nor the acceptance of an ultimately self-defeating cultural relativism." While universal, human rights should reflect the realities of particular contexts. Thus, the acknowledgement of "childness" and the child's specificities, cultural, linguistic or other should not inhibit inclusive rights protection and implementation (Brems, 2002, 32-45). 
Legal pluralism can pose a challenge to the implementation of children's rights including the general measures, not only within a country but across countries. As examples, Canada has both civil and common legal systems and South Africa has common and customary legal systems, which can complicate the implementation of children's rights (Collins, 2007). In addition, international human rights law does not have the same legal or political influence in all states parties. Indeed, whether a state has a monist or dualist legal system influences the status of international law within it (Aust, 2000). Monist systems can incorporate international human rights treaties into domestic law. However, dualist legal systems, including Canada's, separate international obligations unless legislation incorporates an international treaty into domestic law. Dualist countries may gradually include treaty obligations into various domestic laws through transformation, which is not only time-consuming but also requires various measures to implement treaty provisions (Collins, 2007; Pearson and Collins, 2009).

Moreover, federalism's division of power among sub-national governments can pose difficulties for treaty implementation. Articles 26 and 27 in the Vienna Convention on the Law of Treaties (UN 1969) specifically identify the legal principle of pacta sunt servanda, whereby internal law cannot justify a state's failure to implement a treaty. Nevertheless, federalism complicates comprehensive and consistent application across various internal jurisdictions. In relation to Canada, for example, the UN Committee (1995, paragraph 9) has enunciated that federalism and any resulting doubts about aspects of responsibility cannot excuse inadequate

implementation because "Canada is bound to fully observe the obligations entered upon by ratifying the Convention." This paper argues that every order or level of government shares the duty for children's rights and can and should adopt the general measures.

Therefore, the general measures of implementation are shaped by the considerations of rights-based governance and accountability, progressive realization, cultural relativism and legal pluralism in various countries around the world.

\section{Focus on the Global Application of Four General Measures}

The following discussion examines the meaning and application of four of the general measures of implementation with selected references to various examples in states parties. These are law reform, budgeting, monitoring and independent human rights institutions for children, 
Considering the indivisibility and interdependence of children's rights, these four general measures are not more significant than the others, since the ten general measures are most effective when all are in place. These particular general measures were selected for their potential to make a significant impact in advancing children's rights nationally and locally. While some encouraging efforts exist around the world, the general measures vary considerably in the extent to which they are established in different countries. As such, the discussion illustrates the challenges of building a governance architecture that serves children well, and indicates what is necessary in order to realize the architecture for children's rights internationally.

\section{Law Reform}

In accordance with CRC Article 4, children's rights must be incorporated into national legal frameworks, and effective remedies should exist for rights violations. Indeed, the process of law reform constitutes a catalyst for profound cultural changes concerning the role of children in the family and in society (UNICEF, 2005). The UN Committee (2003b, 2) emphasizes that it is "fundamental" to implementing children's rights that states ensure that "all domestic legislation is fully compatible with the [CRC]". Law reform is a long-term process through ongoing review and reform of both existing and new legislation in all sectors or domains (e.g., criminal law, family law, etc.). Moreover, where powers to legislate are shared with, and delegated to, federated or sub-national governments (e.g., provinces and local authorities), these governments must also legislate within the CRC framework in a manner consistent with Article 27 of the Vienna Convention on the Law of Treaties (UN, 1969).

Incorporation (of CRC in legislation) is nearly universal in Central and Eastern Europe and Latin America (UNICEF, 2005). There has been much progress in reflecting CRC commitments in national law in various monist, civil law countries where treaties (in force) form part of the national law - either automatically or through a legislative measure; Czech Republic, Italy, Poland, Slovak Republic, Slovenia, Spain, Japan and Switzerland. Important changes in the law also have been made by the children or family codes adopted by Ethiopia, Nigeria, Libya, Morocco, Tunisia and by legislation adopted by South Africa, India, Japan, South Korea, Sri Lanka, the Philippines and Viet Nam (UNICEF, 2005). However, law and policy coordination is always difficult in the public sector, and may be more difficult in this case 
simply given the range of services that apply to children. Some of those policies, such as services for women, may be, at least in part, competitive with the rights of children (Peters, 2012).

While legal incorporation still requires ongoing efforts to ensure full implementation and to develop new legislation that is rights-consistent, when the CRC is neither incorporated nor adopted through comprehensive children's laws or bills of rights, the legal protection and provision of children's rights is not fully assured and it is more challenging to fulfil rights claims. Reflecting CRC obligations in the national legal framework is generally more difficult in dualist, common law countries, which distinguish between international and domestic law. The CRC neither forms part of the domestic law through incorporation nor through enabling legislation in several common law countries such as Australia, Canada (although Quebec has the civil law system) and the United Kingdom. To some extent, those countries that have not implemented the $\mathrm{CRC}$ into legislation have adopted laws along with regulations and programs to reflect the CRC (UNICEF, 2005). In 2011, the Welsh Assembly Government adopted a unique legal measure, providing that Ministers have a duty to give due regard to the CRC in all their actions. The Standing Senate Committee on Human Rights of Canada (Senate of Canada, 2007) has proposed the adoption of enabling legislation that could legally bind the federal government to its ratified international human rights treaties, which is a valuable compromise (Pearson \& Collins, 2009). Indeed, Norway, which also has a dualist legal system, already has CRC domestic-enabling legislation (UNICEF, 2010a). Such legal commitment would make a valuable contribution to a potential governance architecture for children's rights in dualist states where direct incorporation of the CRC is unlikely.

UNICEF's study of more than 60 countries' experiences with CRC implementation indicates that, as a rule, only a constitutional provision, a children's code or a comprehensive law ensures that the general principles and the full scope of children's rights are mainstreamed into the law (2005). The constitutionalisation of international children's rights is a more recent development (Tobin, 2005; UNICEF, 2007b). If appropriate, the UN Committee recommends that states parties incorporate children's rights in this way. Only two Western European countries (Belgium and Iceland) have amended their constitutions to include children's rights (UNICEF, 2007b, 15). Ireland is an encouraging example of a common law country that may amend its national constitution to include a more explicit commitment to children's rights, ${ }^{2}$ demonstrating 
that progress with the $\mathrm{CRC}$ commitment is possible no matter what the legal system is in a country.

Newer constitutions and newer constitutional amendments have increasingly acknowledged the importance of specific child rights because general human rights commitments do not support children sufficiently (Van Bueren, 2003; Tobin, 2005). Nepal's National Human Rights Commission, for instance, supported the organization of regional workshops to give children the opportunity to contribute to the drafting of the country's new constitution (Sedletzki, 2012). Participation in the legislative and constitutional process is encouraging in some places. For example, child rights inspired a participatory process in Kenya, where after the establishment of the Constitution Review Commission to engage the general public, non-governmental organizations (NGOs) established a Children's Caucus to allow for children's participation in constitutional reform (Vučković Šahović, 2010). After extensive consultations with children, $95 \%$ of their suggestions were incorporated into the final constitution and there was improved public interest in children's rights (Vučković Šahović , 2010).

The route of comprehensive children's laws or children's bills of rights has not been adopted by industrialized countries to date except the Czech Republic's Social and Legal Protection of Children Act, adopted in 2002 to recognize most of the CRC rights and define the corresponding obligations of public agencies and authorities, and Spain's Organic Law on the Protection of Minors, adopted in 1996 (UNICEF, 2005 and 2006). Experience suggests such comprehensive legislation can give greater legal effect to the $\mathrm{CRC}$ by requiring public agencies and policymakers to consider and respect children's rights in all sectors and by justifying a stronger court role in protecting them (UNICEF, 2005).

Governments are required to conduct a comprehensive review of all domestic legislation and related regulations and policies to ensure full compliance with the CRC. However, many states review legislation once (usually during preparations to sign or ratify/accede to the treaty) and amend accordingly if necessary. In this process, assessment of compliance is usually based on the government's own perspective of CRC conformity. The rigour and scope of this government exercise, usually lacking civil society participation, is questionable in many states. The limitations of this procedure are evident in the Canadian example in the variations in 
maximum ages for protection under provincial child welfare legislation, which leave some children less protected than others (Pearson and Collins, 2009).

Moreover, sectoral legal reform may be restricted to certain legislation being perceived as pertinent to children, leaving gaps because there is ultimately no such thing as a child-neutral law or policy (UNICEF, 2001). Therefore, sectoral legal reform should ideally be complemented with Child Rights Impact Assessment (discussed below) and by comprehensive periodic reviews that consider the CRC across legislation, identifying gaps and inconsistencies. Italy's Parliamentary Commission, for example, reviews the need for new legislation and treaties on matters concerning children on a permanent basis (UNICEF, 2010a). In Denmark, children can contribute to legislative reform including proposing new laws (Peters, 2013). These are valuable mechanisms that other states parties should adopt.

Existing and new legislation must also be regularly reviewed in relation to its effect on children's rights as our understanding of childhood and the requirements of children's rights evolve and new policy agendas are pursued. In Sweden, for example, a permanent parliamentary mechanism conducts child impact assessments on all proposed legislation (Sylwander, 2001). The UN Committee outlines that respect for the CRC should be reflected in legislation and policy development and delivery, which

demands a continuous process of child impact assessment (predicting the impact of any proposed law, policy or budgetary allocation which affects children and the enjoyment of their rights) and child impact evaluation (evaluating the actual impact of implementation). This process needs to be built into government at all levels and as early as possible in the development of policy (UN Committee, 2003b, 13).

A Child Rights Impact Assessment (CRIA) is defined as "a tool for assessing the impact of a policy, law, program, or particular decision for children and their rights. The impacts can be direct and indirect, short-term and long-term, and positive or negative. The focus is to understand how the matter under assessment will contribute to or undermine fulfillment of children's rights and well-being” (UNICEF Canada, 2013, 1). In practice, CRIA is carried out by governments, children's commissioners or other children's rights advocacy bodies in Flanders (Belgium), Finland, Sweden, Scotland, Northern Ireland, Australia, England, and other countries (UNICEF Canada, 2013). The Canadian province of New Brunswick now routinely assesses new 
legislation using CRIAs (Government of New Brunswick, 2013). International experiences have identified the following elements for success (UNICEF Canada, 2013): process embedded in legislation with strong commitment; clear understanding on what will be subject to CRIA; use of practical, user-friendly templates and toolkits; inclusion of solutions to potential procedural problems; effective consultations with children and stakeholders; and ideally, transparent, public reporting.

Many countries do not yet have a systematic process for child impact assessment in legislative development and reform. Most processes to assess the impact of draft legislation on children, if they exist, are inadequate to build a legislative framework that fully and consistently accounts for the rights and best interests of children. In some instances, ad hoc approaches to sectoral law reform result in legal approaches and developments that do not comply with the CRC.

Another crucial test of whether treaty rights are legally implemented in a country is the availability of remedies through the courts or other tribunals to address rights-based issues and violations. This requirement is implicit in the $\mathrm{CRC}$, as it is in the other core international human rights treaties (UN Committee, 2003b). However, experience suggests that jurisprudence is not consistently informed by the treaty, and without CRC incorporation there is little adherence to it. Making court enforcement of rights a part of governance lends even greater importance to legislative and executive bodies that act consistently with the CRC. In countries where the CRC is directly incorporated in law or applicable at the constitutional level, the provisions are more likely to be applied by courts (Van Bueren, 2003). Nevertheless, some countries have adopted important jurisprudence based on the CRC despite its absence of incorporation into national law. As examples (UNICEF, 2010a), Denmark adopted a decision on the right of children to be heard and, in common law countries, the United Kingdom is developing valuable jurisprudence based on the CRC and the European Convention on Human Rights while Australia's High Court has recognized the influence of the CRC on the legal framework.

In dualist countries where the CRC is not incorporated in domestic law, it cannot be used as a direct legal claim. In other words, $\mathrm{CRC}$ rights are not justiciable (enforceable in the courts) unless they are protected in existing legislation. However, court decisions in common law countries have a considerable influence on the law. The CRC can and has been used to inform judicial decisions within the scope of domestic law, employing a common-law interpretive 
presumption that Parliament intended legislation to be consistent with international legal obligations. Other court decisions have been made that do not reference the CRC but may have been influenced by it and at least have advanced the jurisprudence. Attention must be directed to training and supporting legal and political actors to advance children's rights in jurisprudence and law reform.

The sum of this experience suggests that incorporating the $\mathrm{CRC}$ into domestic law would provide the courts with a stronger mandate to implement it in jurisprudence. Significantly, it also suggests that the courts, while an important legal mechanism in the protection of children's rights, must be complemented in constitutional democracies by legislatures and parliaments that actively legislate in a manner consistent with the CRC.

There are various challenges to children's rights in law reform. For instance, children's rights may have to "compete" alongside the rights and interests of other groups in legislation and policy and have often been overlooked as a result (Peters, 2012). Since children's rights have been enunciated, greater understanding has advanced of the unique issues children face in the legal sphere. However, it is fair to conclude that law reform has been inconsistently informed by the $\mathrm{CRC}$ in various countries around the world. While there are some positive developments with various laws passed and amended, in terms of law reform, states parties have much room for improvement especially if they do not have constitutional child rights, a national children's bill of rights, a comprehensive law on children or CRC-enabling legislation. Hence, existing and new legislation, as well as the legal interpretation of the $\mathrm{CRC}$ in the courts, provide uneven protection of children's rights, and in some cases are regressive. Given the inadequacies of this limited approach, most states parties have insufficiently implemented the general measure of law reform.

\section{Budgeting and Tracking Expenditures}

While implementing the CRC requires human and technical resources (Himes, 1992), monitoring financial allocations and expenditures enables assessment of the extent to which states parties are fulfilling CRC rights. CRC states parties have pledged to fulfill children's rights to the maximum extent of available resources (Article 4). Thus, this general measure facilitates the UN Committee (2003b, p. 12) as well as governments and civil society to 
understand the degree of the state's CRC commitment through "the proportion of national and other budgets allocated to...children, both directly and indirectly."

The UN Committee has often emphasized the need for states parties to undertake budgetary analysis, to identify and maximize the resources allocated for the benefit of children and, in particular, the proportion of the budget devoted to social expenditure on child's health, education and welfare at all levels of government (UNICEF, 2005).

An important part of the governance architecture for children's rights then is to publish a “children's budget" that designates resources and evaluates the impact of expenditures for children, including attention to equity and the best interests of children as CRC Articles 2 and 3 require. A children's budget should illustrate changes in resource allocation over time, and investment in children relative to other expenditures. Ideally, a children's budget would "reveal the degree to which children are treated equitably on the basis of age, geography, ethnicity and other meaningful criteria, and it would be publicly available and monitored by government and by civil society" (Collins and Wolff, 2012, p. 15).

This general measure of budgeting has several challenges in states parties. First, only three out of every four budget documents from 85 developing and industrial countries are released to the public (UNICEF, 2010b). The Open Budget Survey (2008) found that such countries as France, New Zealand, South Africa, UK, and US ranked highly in their open budget index performances in contrast with other countries including Afghanistan, Algeria, Vietnam, Yemen that ranked the lowest (Gore, 2010). Hence, the International Budget Partnership (IBP) recommends global budget transparency where the public would have better access to budget data and documents to support transparency to prevent and eliminate corruption and allow the public to support adequate budgetary allocations (UNICEF, 2010b). Second, 19 out of 30 OECD countries do not have a specialized budget research office to examine budget practices and procedures (Gore, 2010). Third, in times of serious economic downturn, war, and/or natural disasters, countries will often relocate funding from social services - often including children's services - to meet other needs (Peters, 2012; and UNICEF, 2005). Children often do not have an organized, powerful voice to advocate for resources and ensure their best interests are given priority, highlighting the importance of supporting their rights through specific financial accountability mechanisms such as publishing and monitoring expenditures on children. 
Despite fiscal challenges, a study of recent public expenditures from 126 countries has identified options for policymakers to increase social and economic support for children in vulnerable countries, including low income contexts. These options include (Ortiz et al., 2010, pp. 25-26):

- Reallocating public expenditures: assessing budget distribution through reviews and eliminating spending inefficiencies;

- Increasing tax revenue: including the improvement of the efficiency of tax collectionconsumption, corporate profits, financial activities, personal income;

- Increasing aid and transfers: working with other governments to reduce illicit financial flows;

- Using fiscal and foreign exchange reserves: spending fiscal saving or other state revenues stored in special funds;

- Borrowing or restricting debt: and

- Adopting a more flexible macroeconomic framework: advancing expansionary fiscal and monetary policies - allowing for higher budget deficit and levels of inflation.

Hence, various avenues exist to improve children's budgeting and allocations even in the most difficult circumstances.

Globally, efforts to publish children's budgets are proliferating in developing countries as part of their commitment to children's rights, in part because of requirements from multilateral aid institutions and advocacy by international NGOs. In contrast, only four of the 32 industrialized states parties to the CRC (Sweden, Wales, Andorra and Norway) publish a specific "children's budget" (UNICEF, 2007a). Most governments have little idea what proportion of their budget is spent on children and few can measure the impact of their expenditures on children (UNICEF, 2007a). Children have the least influence on economic policy and tend to be invisible in public accounts (Pearson \& Collins, 2009). In a growing number of countries, however, there are efforts to make information more available on allocations benefiting children. In Belgium, information on the expenditures of the sub-national Flemish government programmes for children is published annually, and the Children's Observatory publishes an annual estimate of the French Community's expenditures on children (UNICEF, 2010a). The 
Children's Commissioner in Northern Ireland publishes a similar analysis of the government budget (UNICEF, 2010a).

In other countries, more commonly, there is no comprehensive view of what different departments and governments spend on children, and no informative, accessible way for parliamentarians and civil society to monitor trends in spending and evaluate outcomes. Despite the challenges in defining "children's budgets," the information can highlight disparities and efficiencies in the allocation of resources to give priority to children and advance their rights and well-being.

In some cases, ad hoc reports by external organizations reveal concerns about government expenditure patterns. External monitoring of the expenditures of countries on children, such as the UNICEF Report Card series and Organization for Economic Cooperation and Development (OECD) reports, also provides useful international comparisons on specific issues from time to time. Consequently, UNICEF is working with finance ministries in Bosnia, Herzegovina, Bulgaria, Romania and countries in Central Asia to support public finance management in relation to children's rights providing national-level training to support understanding of child-focused budgeting including attention to expenditures and policy changes (Channon, 2012).

Published information on the allocation of resources and evaluations of the results for children constitutes a useful tool to promote accountability for children's rights. It can help correct a policy mid-course, or it can attract continuing investment in a successful one. Globally, information is available in most industrialized countries on public expenditures for certain services that benefit children such as education, health, child care and income transfers. Available information indicates that public expenditures for services that benefit children have increased during the past decade. Australia, Belgium, Scotland, Ireland, Spain, Sweden and Italy increased investments in areas such as child health, education and social benefits (some as much as 30 percent), though there is not sufficient understanding of the current and lingering impact of the international economic downturn of recent years (UNICEF, 2010a). What is often more difficult to identify and calculate is the amount spent on other social programmes benefiting children, cultural and recreational programmes, and expenditures in areas such as law enforcement or the administration of justice designed to protect children's rights. Ultimately, the purpose of doing so is to monitor whether changes in resource allocation over time are 
generationally balanced and whether investments are directed to effective programs and services that meet evidenced need, equitably.

While governments have the duty to implement the CRC, both government and civil society organizations should monitor expenditures for their impacts, for children generally and for specific populations of children. Civil society organizations are already involved in applied budget monitoring in some countries and international projects (e.g., Www.internationalbudget.org). In general, though, budget monitoring is either absent or poorly developed, even though it is significant in determining child rights commitments and the UN Committee (1996) specifically requests it. The Children's Budget project of the Institute for a Democratic South Africa (IDASA) was an international leader in this area and provided capacity building on budgeting monitoring tools for civil society and government (see Cassiem and Streak (2001); Cassiem et al. (2001)). Unfortunately, IDASA's pioneering work has since come to an end due to its 2013 closure (Graham, 2013). This activity has been taken up by some other organizations around the world. For instance, the Centre for Child Rights (HAQ) in India concluded that budget analysis would support understanding of government financial commitments to children but since India is large and diverse, rather than focus on central government budgets, it began by analysing the state budgets of three states and then expanded to seven by 2006 (Vučković Šahović, 2010). In collaboration with these Indian states, HAQ supports partner state-level organizations to build their capacities in order to advocate at the local level (Vučković Šahović, 2010). Consequently, HAQ’s work led the Indian government to undertake such analysis for both the Union and states and child budgeting is included in the governmental National Plan Action for Children (Vučković Šahović, 2010).

In a small but growing number of industrialized countries, research institutions, NGOs and children's commissioners have begun to monitor budget allocations. In Italy, for example, a coalition for the rights of children monitors the resources allocated for children by regional governments biannually. In Canada, civil society participates in budget monitoring activities in an ad hoc way including the Caledon Institute of Social Policy the Canadian Centre for Policy Alternatives, the Assembly of First Nations and First Nations Child and Family Caring Society, although the analyses do not extend to a comprehensive focus on children. In Brazil, a local NGO, Cedeca-Ceará supports children's participation in monitoring the public budget of the city of Fortaleza, which also led to the mobilization of more vulnerable youth, and resulted in greater 
public visibility of youth organizations and an additional R $\$ 2$ million for children's development in the public budget (Nguyen, 2013). Other examples include Malawi’s Civil Society Coalition for Quality Basic Education aggregates school budgets at a national level, names poorly maintained public school assets and recommends timing for funds' release (Gore, 2010). The Philippines' Concerned Citizens of Abra for Good Government identifies discrepancies in government reports, supports project funding as intended, and includes project beneficiaries in monitoring work (Gore, 2010). In India, the Budget Analysis Rajasthan Centre (BARC), in collaboration with Save the Children in Rajasthan, Oxfam and Action Aid, analyzes the state budget in order to address corruption and support the proper allocation of resources to meet children's needs (Save the Children, 2004). For instance, a BARC workshop involving 50 tribal boys and girls between the ages of 12 to 18 , asked about the budget for their government school hostels and found that specific items budgeted for were not provided since the young people indicated that they never received toothpaste, toothbrushes, vegetables, rice, fruit or a second set of clothes (Save the Children, 2004). Consequently, hostel wardens have since been instructed to provide the budgeted money to hostel student committees every month (Save the Children, 2004). Such participatory efforts are important to identify the requirements of budget allocations and ascertain the reality of budget expenditures.

In general, however, there are no coordinated efforts in most governments or in civil society in CRC states parties to comprehensively and systematically monitor and report on budgets or expenditures for children. This void is due to either lack of capacity or interest, resulting in many gaps in understanding and assessing this general measure. Yet, there are many benefits to transparent children's budgeting. As Fisher and Dudding (2006) highlight, advantages include improved coordination between economic and social policies, the reduction of discrimination between regions and groups of children in service provision, children's protection from adverse economic policies, and the promotion of children as a population deserving priority consideration.

\section{Monitoring Processes and Mechanisms}

Monitoring the situation of children's rights is an essential general measure in the governance architecture for children (Collins and Wolff, 2012). Monitoring refers to the 
collection and assessment of data to ascertain progress in implementing the CRC and its public reporting (Collins, 2008a). In other words, this process provides the information to hold states parties accountable for their actions or lack thereof and support evidence-based decision-making and child rights progress. Monitoring should examine both the situation of children in the country and the state of the laws, policies, budgets and other measures in place to secure children's rights. Monitoring should be part of tracking the implementation of another general measure: a comprehensive strategy to support progress for children's rights. Monitoring should produce a consolidated, national picture of children. Data should also be disaggregated by age, gender, social or ethnic background, region and rural or urban residence to identify the situation of vulnerable groups. Too often, national and even sub-national averages hide the disparities between groups of children including indigenous children and children with disabilities, and other marginalized children. Without that information, measures will fail to reach all children adequately without discrimination. A comprehensive national data collection system will: support identification of areas of rights implementation that are weak and may require greater attention and investment; reveal which policies and investments are yielding good outcomes; and act as an early warning system for emerging concerns.

The UN Committee (2003b, 13) recognizes self-monitoring as an obligation of governments; the collection and reporting of "sufficient and reliable data" on children, complemented by independent monitoring by parliamentary committees, academics, and NGOs. Self-monitoring has its limitations due to the critical analysis required (Peters, 2012). Additional monitors should be involved, as two 13 year-old Canadian boys explain, in order: "To get accurate information from the parties involved and to have proof that directives [of the Convention] are being followed. ....Monitoring is important...to get many diverse opinions" (Collins, 2008a, 6-7).

Different approaches to monitoring can be discerned that influence the process and results in different ways (Collins, 2008b). Broad participation is necessary to create a balanced, accurate understanding of the situation of children's rights. It is encouraging, then, that the Grand National Assembly in Turkey established a committee in 2008 to monitor children's rights, and recognized that children should contribute to the committee's deliberations (Peters, 2012). However, there can be challenges of coordination and inconsistent data collection even in 
multi-stakeholder efforts (Peters, 2012). Monitoring should involve attention to a comprehensive system of data collection, disaggregation of data, and child participation (see Collins, 2015).

Globally, many industrialized countries have centralized systems for data collection and monitoring on children but few, if any, national data collection systems cover the whole range of rights contained in the $\mathrm{CRC}$, and relatively few indicators can be described as rights-based. Countries also vary considerably in the way they collect and disaggregate data to identify disparities demonstrating that regular national data collection and monitoring is possible in different ways. The Republic of South Korea uses a child rights index containing 40 indicators covering a broad spectrum of rights (e.g., education, health, family, culture, leisure, access to information, labour and safety) in the development of programmes and policies, published in an annual Yearbook on Children and Youth (UNICEF, 2010a). In the UK, the government has established its own monitoring system in order to assess the efforts of different governmental departments in relation to child well-being through 25 indicators organized into five major headings: "be healthy; stay safe; enjoy and achieve; make positive contribution; achieve economic well-being” (original emphasis, UNICEF, 2007c, p. 40). In 2006, Australia adopted an Information Development Plan on Improving Statistics on Children and Youth, and data collected in accordance with the plan is published annually (Trewin, 2006). International efforts include the European Union's development of comprehensive children's rights indicators for use by its members that constitute a conceptual leap forward in monitoring children's rights (Stalford and Sax, 2009). Inspired by the CRC, UNICEF's periodic report cards rank industrialized countries in multiple domains of child well-being: health and safety, education, peer family relationships, behaviors and risks, young people's own subjective sense of well- being, and material well-being. A group of international multidisciplinary experts launched the MultiNational Project for Monitoring and Measuring Children's Well-being, developed as a response to UNICEF's Progress of Nations report, that monitors the situation of children in developing countries (UNICEF, 2007c). Specialized monitors are also active internationally including (Peters, 2012): the International Labour Office, which assesses and reports on child exploitation in the labour market, and reporting; the Food and Agriculture Organization monitors inter alia child hunger and malnourishment; and the international criminal police organization, INTERPOL, monitors various crimes against children. 
Most countries, however, do not have a comprehensive national system for data collection to monitor CRC implementation or the state of children. There are few robust examples of indicator-based or outcome-related reporting on the status of children's rights and the situation of children based on the comprehensive scope of the CRC. If statistics on the situation of children are collected at national and sub-national levels, coordinating mechanisms often do not exist to promote the development, comparability or consolidation of data.

Despite the volume of statistical data submitted by the Government of Canada in its last periodic report on CRC implementation, the UN Committee $(2012,4)$ reiterated the same concern expressed during the earlier periodic review (2003a) about Canada's insufficient development of data collection and analysis (a significant example is the lacuna of "data on the number of children aged 14 to 18 years old placed into alternative care facilities"), recommending the establishment of a national, comprehensive data collection system and means to analyze the data in relation to child rights. Not only would coordinated data collection and assessment benefit CRC monitoring, but a better understanding of the situation of children would advance consensus on legislative, policy and other governance measures to address gaps in CRC implementation.

While governments have the duty to monitor children's rights, civil society should also participate and contribute to the assessment from their viewpoints. Participatory monitoring should include children; it is their right (Article 12) and research with children would help illuminate the extent to which their rights are realized (Collins, 2015). Nonetheless, systematic collection of information from children across the globe continues to be rare. There are exceptions including the World Health Organization's (WHO) Health Behaviours in School-age Children Study (2014), and the German Youth Institute (2014), an independent body funded largely by the German government that conducts surveys of children on a regular basis. In Finland, surveys are carried out regularly on the rights of older children to participate in schools (UNICEF, 2010a). Media organizations around the world also play an important role in monitoring children and providing children's access to information (Peters, 2012).

Consultations with children to monitor their rights have been carried out in (Collins, 2015): Bangladesh (Adolescent Development Foundation 2008), and Afghanistan (2009), and focus groups utilised in Seychelles $(\mathrm{Vel}, 2011)$ and in a multinational study of children in 
conflict in Democratic Republic of Congo/Côte d'Ivoire/Nepal (Barnett and Jefferys 2008). Children themselves have researched and analysed child rights in reports from countries around the world including (Collins, 2015): Scotland (Article 12, 2008), Cambodia (2010), and Yemen (Children's Parliament 2008). Funky Dragon (2012) in Wales has created a video about its participatory CRC monitoring process.

When such information is collected, it is generally on an ad hoc basis and focuses on specific issues, views and experiences of older children. Other issues include (Collins, 2015): limited awareness about monitoring, and different interpretations of participation. For this reason, there is significant room for improvement with respect to the meaningful engagement of children in the monitoring process.

Monitoring is also challenged by such international issues as trafficking of children and exploitation through the Internet and other technologies that inhibit efforts of individual countries to implement their CRC commitments (Peters, 2012).

The general measure of monitoring the state of children and their rights has not yet advanced in most contexts as part of a strong governance architecture for children and their rights. Regular monitoring of the status of children and their rights based on indicators addressing the comprehensive application of the CRC could improve governance for children, enabling better policy and budgeting decisions. The participation of children, civil society and legislators in the creation and use of monitoring reports would support more effective decisionmaking, implementation of children's rights and enforce accountability.

\section{Independent National Human Rights Institutions for Children}

The creation of national human rights institutions has been a very significant development in human rights in recent decades (UNICEF, 2005). As independent actors, these institutions -known as ombudspersons, advocates, representatives and commissioners advocate and monitor at the national and sub-national levels without political or government interference (Collins and Wolff, 2012). Within this framework, a dedicated mechanism for children is necessary given that children's developmental state and lack of political voice make them particularly vulnerable to rights violations, and that the judicial system is not always the appropriate mechanism to resolve them. Moreover, without a dedicated independent institution 
children's rights can be ignored, the impact of government efforts upon children unconsidered and children's perspectives unheard.

Independent institutions bring an explicit children's focus to traditionally adult-oriented governance systems. Often offering direct mechanisms for greater accountability of the state and other duty bearers for children, they fill gaps in checks and balances and make sure that the impact of policy and practice on children's rights is understood and recognized. They support remedy and reform when things have gone wrong or results are inadequate (Sedletzki, 2012, 4).

These institutions advance the CRC and government accountability by examining individual and systemic violations of children's rights, monitoring the situation of children and government actions, creating broad awareness of children's issues, participating in policy development and otherwise contributing to the implementation of various accountability mechanisms.

The UN Committee (2002 \& 2003b) recognizes the important contribution of children's ombudspersons, advocates and commissioners. Together with the Paris Principles for Independent Human Rights Institutions (United Nations, 1993), these guidelines outline the fundamental criteria of these offices including: statutory independence; sufficient investigatory powers; complaint mechanisms; broad latitude for monitoring and reporting; assessment of legislation and policy consistent with the $\mathrm{CRC}$; intervention in or initiation of legal/judicial proceedings; education and awareness; and facilitation of children's participation. These characteristics must be set in legislation to outline and preserve the authority, efficacy and role of independent institutions for children relative to Parliament, the courts and civil organizations. Children's commissioners play a highly effective role in the governance architecture for children. UNICEF (2005) highlights many examples of actions favouring the rights of children to which children's commissioners have contributed substantially such as improving the visibility of children in government and in society, advancing legislation and policy through dialogue, and promoting accountability. Many countries, including England and Australia, also have strong national government departments for children. Children's commissioners do not 
replace the responsibility of the government, but rather they monitor it and contribute to its efficacy as part of the governance and accountability architecture.

Globally, more than 70 countries have established children's commissioners with the most rapid spread in Europe (Sedletzki, 2012). These institutions exist in the United Kingdom (with designated children's commissioners in England, Wales, Scotland and Northern Ireland), New Zealand, Norway, Denmark, Finland, France, Poland, Luxembourg, Sweden, Australia and Austria (European Network of Ombudspersons for Children (n.d.)). In some countries, there are commissioners that focus exclusively on children's rights; in others, human rights commissions or ombudspersons have specialized child units such as in Spain and Slovenia. Children's commissioners have also been established at federal, provincial and municipal levels, as well as within systems such as schooling and health care. In Kazakhstan, the Office of Human Rights Commissioner opened a special section with responsibility for children's rights and created a pilot project in order to establish a children's rights ombudsman in every region of the country, partnering with 90 representatives of the Ministry of Education and Science, the Ombudsman's office, local authorities, NGOs and the media as well as 3000 children under 18 years of age (Vučković Šahović, 2010).

National human rights institutions play an important role around the world in focusing on vulnerable children in their jurisdictions and supporting children's rights. There are many examples including (Sedletzki, 2012, pp. 10-21):

- In early 2012, the Children's Commissioner for England illuminated the treatment of unaccompanied asylum-seeking children arriving in the United Kingdom from France and their potential rapid return without due attention to their best interests, leading the border authorities undertaking to stop the practice.

- In 2006, the Defensoría del Pueblo in Colombia identified risk factors for child soldier recruitment, which then informed recommendations for effective programming to support the reintegration of demobilized child combatants.

- Peru's Deputy Ombudsman for Children and Adolescents visits state residential centres for children and evaluates their functioning and the level of respect of children's rights.

- The Human Rights Commission of Malaysia monitors the conditions of detention of juveniles while reviewing detention facilities, which includes immigrant detention centres. 
- In 2010, the Canadian Council of Child and Youth Advocates recommended a national plan to improve the well-being and living conditions of Canada's Aboriginal children and youth.

- Due to the efforts of the Persons with Disabilities Unit of the Afghanistan Independent Human Rights Commission in 2009, most schools and public buildings built in the country are equipped with ramps.

- Officials from Uganda's Human Rights Commission visited camps for internally displaced persons in the north of the country and raised awareness about their situation during the conflict.

Due to concerns that children's rights have been inadequately addressed, there are now more separate children's rights institutions than child rights offices included in more general human rights institutions or commissions (UNICEF, 2005, 10). However, increasing numbers of states parties are considering merging human rights institutions in order to mainstream rights, rationalize and reduce costs. Nevertheless, potential benefits must be balanced with the potential risks (Sedletzki, 2012, 15). Attention to these developments, including the extent of the independent nature of these institutions, is important. Consequently, the work of the Asian NGO Network on National Human Rights Institutions, for example, is welcomed since it produces "an annual report on the functioning and independence of national human rights institutions" (Sedletzki, 2012, 18). The International Coordinating Committee of National Human Rights Institutions also plays an important role in monitoring and accrediting human rights institutions in terms of their compliance with the Paris Principles but it does not, however, assess separate human rights institutions for children or institutions established only at the local level (Sedletzki, 2012).

It is significant that "children themselves make proportionally few complaints to independent institutions" (Sedletzki, 2012, 20). While there is a need for better understanding of the challenges, Sedletzki (2012) identifies such potential reasons as other, better-known avenues for children to seek help including child helplines, the limited visibility of institutions among children, and inappropriate or inaccessible complaint mechanisms for them. For instance, a survey found that only four out of 10 adults in France in 2010 knew about the Défenseur des enfants revealing that this institution was not well known (Sedletzki, 2012). The lack of 
awareness is exacerbated among many young people by the general absence of references to independent child rights institutions in school curricula (Sedletzki, 2012).

Despite these positive contributions, there is a significant gap at national levels around the world. In Canada, for instance, there is no statutory national human rights institution for children, though nine of ten provinces and two northern territories (that derive their power from the federal government unlike the provincial governments with their own constitutionallymandated authority) have child advocates, commissioners or ombudspersons. In Canada, in contrast to many other countries, the mandates of these independent advocates are in some jurisdictions limited to one or several government service domains rather than the full scope of children's rights. Establishing independent children's commissioners at all levels of government with mandates consistent with the UN Committee's guidance and the Paris Principles would make a valuable contribution towards an effective governance architecture in countries around the world.

\section{Conclusion and Recommendations}

The CRC has real significance for children and for all those around them. The general measures of implementation create and sustain an overall architecture for governing that demands consideration of children and accountability for the protection and provision of their rights. There are many interconnections between the general measures, which should be fostered for each to work to its best potential. While Ireland's Ombudsman for Children has a clear mandate to support law reform for example, other independent human rights institutions must rely upon others to inform them about policy initiatives with adequate time to influence outcomes, or resort to advocacy through other means (Sedletzki, 2012). The interdependence of rights is highlighted in the relationship between CRC awareness and the other general measures of implementation. With successful efforts to promote government and public understanding of children's rights, support for the general measures and accountability can be advanced through training for government and through awareness-raising initiatives involving adults (parents, grandparents, educators, medical professionals and so on) and children including such activities as budget monitoring. The UN Committee (2003b, 15-16) explains the importance of the CRC provision's about awareness: 
Traditionally in most, if not all, societies children have not been regarded as rights holders. So Article 42 acquires a particular importance. If the adults around children, their parents and other family members, teachers and carers do not understand the implications of the Convention, and above all its confirmation of the equal status of children as subjects of rights, it is most unlikely that the rights set out in the Convention will be realized for many children.

A closer look at how states parties have supported the architecture for CRC implementation and accountability suggests that while there has been some progress, considerably more building of the governance structures that influence children's lives is needed. Children's rights require dedicated political and public will and commitment to advance progress with implementation. Such progress will be much more achievable with an adequate architecture upon which to build a truly protective and enabling governance framework for a large but vulnerable and comparatively voiceless constituency.

To strengthen the governance architecture for children, states parties must take four practical steps (Collins and Wolff, 2012):

1. Ensure children's rights are part of the domestic legal framework if they are not yet incorporated or enabled. Create a reform agenda to ensure all legislation complies with the CRC and other international standards for children and redress any gaps. Child Rights Impact Assessments should also be carried out consistently with any legislative change to avoid adverse effects on children.

2. Publish a children's budget to identify and consistently monitor allocations and expenditures for children to ensure their visibility and efficiency, and to balance the allocation of resources.

3. Monitor children's rights regularly in a broad, participatory manner to inform public priorities and support a system of accountability for children's rights.

4. Establish and effectively maintain an independent children's commissioner (or appropriate institution) in each government jurisdiction, if one does not yet exist, dedicated to promoting children as a priority. 
Moreover, these general measures will be supported through the adoption of a comprehensive CRC awareness, education and training strategy in government and across society.

In conclusion, a rights-based approach is necessary as the UN Committee explains (2003b, 3): "States must see their role as fulfilling clear legal obligations to each and every child. Implementation of the human rights of children must not be seen as a charitable process, bestowing favours on children." There should be no question about the correct answer to the 16year-old boy from Sydney, Nova Scotia (Save the Children, 2001, 35) who said: "The children of today have rights, the adults of today have rights ... shouldn't our rights be noticed as much as yours?"

\section{Acknowledgements}

Many thanks for the valuable research assistance provided by Saadya Hamdani, Jessica LukeSmith, Rachel Roberts and Masi Wali. The authors also appreciate the helpful comments from the anonymous peer-reviewers on an earlier draft of this paper.

\section{Notes}

${ }^{1}$ In relation to some of these international examples, UNICEF developed an approach to monitor countries' progress in applying the ten general measures of implementation, based on a matrix of 40 indicators, four per measure. While the qualitative and subjective analysis of the degree of implementation of these mechanisms challenges the use of binary quantitative indicators of the presence of each general measure, discussion of these indicators is designed to contribute to ongoing national dialogue on child rights progress. UNICEF's analysis is based largely on reports to the Committee on the Rights of the Child from governments, and contributions from civil society organizations and researchers. Although these mechanisms apply to both national and subnational levels of government, the national government is expected to lead amd thus, the focus of this analysis.

${ }^{2}$ See further Collins, 2013; and Shannon, 2014. While a children's rights referendum introduced a new provision into the Irish constitution in 2012, it has not yet become law due to judicial challenge. 


\section{References}

Adolescent Development Foundation. (2008). UNCRC Alternative Report to $3^{\text {rd }} \& 4^{\text {th }}$ Periodic Report from Bangldesh: Looking Through Adolescent Lens. Chittagong: Adolescent Development Foundation. Retrieved March 16, 2014 from: http://www.crin.org/docs/Bangladesh_ADF_NGO_Report.pdf

Afghanistan UNCRC Civil Society Coalition. (2009). Every Single Right for Every Single Child. NGO Alternative Report on the Implementation of the Convention on the Rights of the Child Afghanistan. Retrieved March 17, 2014 from: http://www.crin.org/docs/Afghanistan_ACRCC_NGO_Report.pdf

Alston, P. (1994). The Best Interests of the Child: Reconciling Culture and Human Rights. Florence and Oxford: UNICEF and Clarendon Press.

Alston, P. \& Tobin, J. (2005). Laying the Foundations for Children's Rights: An Independent Study of some Key Legal and Institutional Aspects of the Impact of the Convention on the Rights of the Child. Florence: UNICEF Innocenti Research Centre.

Article 12 in Scotland. (2008). I WITNESS: THE UNCRC IN SCOTLAND. Burnbank, Ogilvie Terrace, Ferryden, Montrose, Angus: Article 12 in Scotland. Retrieved from http://www.crin.org/docs/I_\%20WITNESS\%20_THE_\%20UNCRC_\%20IN_\%20SCOT LAND\%20.pdf

Aust, A. (2000). Modern Treaty Law and Practice, Cambridge: Cambridge University Press.

Barnett, K. \& A. Jefferys (2008). Full of promise: How the UN's Monitoring and Reporting Mechanism can better protect children. No. 62. Humanitarian Practice Network. Retrieved from: http://www.odihpn.org/documents/networkpaper062.pdf 
Black, M. (1994). Monitoring the Rights of Children: Innocenti Global Seminar Summary Report, Florence: UNICEF International Child Development Centre.

Brems, E. (2002). Children's Rights and Universality. In J.C.M. Willems (ed.), Developmental and Autonomy Rights of Children: Empowering Children, Caregivers and Communities (pp. 21-45). Antwerp, Oxford, New York: Intersentia, 21-45.

Cambodia Children and Young People Movement for Child Rights (2010). Cambodian Children's Report: My Life..My Suggestions. Phnom Penh: Cambodia Children and Young People Movement for Children's Rights. Retrieved March 17, 2014 from: http://www.crin.org/docs/Cambodia\%20\%5BChildren's\%20Report\%5D_My\%20Life...M y\%20Suggestions_CCYMCR.pdf

Cassiem, P and Streak, S. (2001). Budgeting for child socio-economic rights: Government obligations and the child's right to social security and education. Cape Town: IDASA.

Cassiem, Perry, Sadan, Streak and Budget Information Service, Institute for Democracy in South Africa (IDASA). (2001). Child Poverty and the Budget in South Africa: A South African Child-Focussed Budget Study. Stockholm: Save the Children Sweden.

Channon, John. (2012). Putting Children at the heart of budgets. Oxford: Oxford Policy Management.

Children's Parliament. (2008). First Report by the Children's Parliament on The Conditions of Children in Yemen. Save the Children. Accessed 16 March 2014. http://mena.savethechildren.se/PageFiles/2867/Children\%20parliament $\% 20 \% 20 \mathrm{in} \% 20 \mathrm{Ye}$ men\%20-\%20shadow\%20report.pdf

Collins, T. (2008a). Monitoring: More than a report. In T. Collins, R. Grondin, V. Pinero, M. Pratte, \& M.C. Roberge (eds.), Droits de l'enfant : Actes de la Conférence internationale 
(Rights of the Child: Proceedings of the International Conference Ottawa, 2007). Wilson \& Lafleur, Montreal, 2008.

Collins, T.M. (2008b). The Significance of Different Approaches to Monitoring: A Case Study of Child Rights, International Journal of Human Rights, April, 12,159-187.

Collins, T.M. (2013). International Child Rights in National Constitutions: Good sense or nonsense for Ireland, Irish Political Studies, 28 (4), 591-619. http://www.tandfonline.com/doi/full/10.1080/07907184.2013.838951

Collins, T.M. (forthcoming 2015). Child Participation in International Monitoring of Children's Rights. In T. Gal, and B. Faedi Duramy (eds.), International Perspectives and Empirical Findings on Child Participation: From Social Exclusion to Child-Inclusive Policies. New York: Oxford University Press.

Collins, T.M. and Lisa Wolff. (2012). Canada's Next Steps for Children's Rights? Building the Architecture for Accountability through the General Measures of Implementation of the CRC, In Ellen Murray (ed.), Children Matter - Exploring Child and Youth Human Rights Issues in Canada. Mount Royal University, Calgary, Alberta.

Fisher, N., UNICEF Canada, \& Dudding, P. Child Welfare League of Canada (2006). Letter to The Honourable James Flaherty, Minister of Finance [Canada], 29 June 2006. Retrieved from http://www.cwlc.ca/files/file/policy/ChildrensBudgetLetter_July2006.pdf

Funky Dragon. (2012). Our Rights Our Story. Swansea: Funky Dragon, Retrieved 17 March, 2014 from http://www.youtube.com/watch?v=GOYm2KNkiS8

German Youth Institute. (2014). German Youth Institute (Deutsches Jugendinstitut e.V. , DJI). Retrieved from http://www.goethe.de/wis/fut/prj/for/jug/en8450228.htm 
Gore, R. (2010). UNICEF-EC Child Rights Toolkit: Chapter on Social Budgeting. UNICEF. Retrieved from http://www.childimpact.unicef-irc.org/documents/view/id/78/lang/en

Government of Canada, Canadian International Development Agency, Political and Social Policies Division, Policy Branch. (1999). Annual Report: CIDA's Programming in Support of Children, Fiscal Year 1996-97. Hull, Quebec: Minister of Public Works and Government Services Canada.

Government of New Brunswick. (2013). Children's Rights Impact Assessment (CRIA): Updated April 2013. Retrieved from http://www.unicef.ca/sites/default/files/imce_uploads/BLOG/new brunswick_cria_form -_eng.pdf

Graham, Paul. (2013). Idasa announces closure and provisional liquidation, Retrieved from http://www.polity.org.za/article/idasa-announces-closure-and-provisional-liquidation2013-03-26

Hammarberg, Thomas. (2009). Speech on $20^{\text {th }}$ Anniversary of the Convention on the Rights of the Child. Retrieved from http://www.crin.org/enoc/resources/infodetail.asp?id=21270

Harris-Short, S. (2003). International Human Rights Law: Imperialist, Inept and Ineffective? Cultural Relativism and the UN Convention on the Rights of the Child, Human Rights Quarterly, 25, 130-181.

Howard, C. \& McGrath, J. (2005). FINALY! (Futures in Newfoundland and Labrador's Youth): Address to the Standing Committee on Human Rights, Ottawa, June 13th. 
Landon Pearson Resource Centre for the Study of Childhood and Children's Rights. (2007). Shaking the Movers II - Speaking truth to power: Civil and political rights of children, Final Report, Ottawa: Landon Pearson Resource Centre for the Study of Childhood and Children's Rights. Retrieved from www.landonpearson.ca

Landon Pearson Resource Centre for the Study of Childhood and Children's Rights (2009). Shaking the Movers III-Child Rights in Education: CRC Articles 28, 29, and 42. Final Report, Ottawa: Landon Pearson Resource Centre for the Study of Childhood and Children's Rights. Retrieved from www.landonpearson.ca

National Council of Welfare. (2008). Welfare and Incomes, 2006 and 2007. Winter 128. Ottawa: National Council of Welfare.

Vučković Šahović, N. (2010). The Role of Civil Society in Implementing the General Measures of the Convention on the Rights of the Child,. UNICEF Innocenti Working Papers 201018. Florence: UNICEF Innocenti Research Centre.

Ngyuyen, L. (2013). Child-responsive Accountability: Lessons from Social Accountability. UNICEF, Office of Research.

Office of the High Commissioner for Human Rights. (2006). Frequently Asked Questions on a Human Rights-Based Approach to Development Cooperation, United Nations, New York and Geneva. Retrieved from http://www.ohchr.org/Documents/Publications/FAQen.pdf

Ortiz, I., Chai, J., Cummins, M., Vergara, G. (2010). Prioritizing Expenditures for a Recovery for All: A Rapid Review of Public Expenditures in 126 Developing Countries. UNICEF: Retrieved from http://www.unicef.org/socialpolicy/files/Prioritizing Expenditures for a Recovery for All_October_11_final.pdf 
Pearson, L. \& Collins, T. (2009). Not there yet: Canada's implementation of the general measures of the Convention on the Rights of the Child. Florence: UNICEF Innocenti Research Centre and UNICEF Canada.

Peters, B. Guy. (2012). Governance and the Rights of Children: Policy, implementation and monitoring, Innocenti Working Paper 2012-11. Florence: UNICEF Innocenti Research Centre.

Save the Children Canada. (2001). A Canada Fit for Children: A report on the realities for young people in Canada today. Toronto: Save the Children Canada, July.

Save the Children UK. (2004). Where's the Money Going? Monitoring government and donor budgets. London: Save the Children Fund.

Senate of Canada, Standing Committee on Human Rights. (2007). Children: The Silenced Citizens: Effective Implementation of Canada's International Obligations with Respect to the Rights of Children. Ottawa: Senate of Canada.

Sedletzki, Vanessa. (2012). Championing Children's Rights: A global study of independent human rights institutions for children, Florence: UNICEF Innocenti Research Centre.

Shannon, Geoffrey. (2014). Place of children in Irish society, The Irish Times, April 25 Retrieved from http://www.irishtimes.com/sponsored/place-of-children-in-irish-society1.1765543 ?page $=1$

Stalford, H. \& Sax, H. (2009). Developing indicators for the protection, respect and promotion of the rights of the child in the European Union: Final Report. Vienna: European Union Fundamental Rights Agency, March. Retrieved from http://fra.europa.eu/fraWebsite/attachments/RightsofChild summary-report en.pdf 
Sylwander, L. (2001). Child Impact Assessments: Swedish Experience of Child Impact Analyses as a tool for implementing the UN Convention on the Rights of the Child. Stockholm: Ministry of Health and Social Affairs \& Ministry for Foreign Affairs, Sweden.

Tobin, J. (2005) Increasingly seen and heard: the constitutional recognition of children's rights, South African Journal of Human Rights, 21, 86-126.

Trewin, D. (2006). "Information Paper: Improving Statistics on Children and Youth: An Information Development Plan Australia”. Retrieved from http://www.abs.gov.au/ausstats/abs@.nsf/5436b5f8368381b8ca25722e0016c824/685fad6 417c73600ca2572ac00121dba/\$FILE/ABS\%20Draft\%20Children\%20and\%20Youth\%20 IDP For\%20comment.pdf

UNICEF. (2001). Independent Institutions Protecting Children's Rights. Innocenti Digest No. 8. Florence: UNICEF Innocenti Research Centre.

UNICEF. (2005). Summary Report of the Study on the Impact of the Implementation of the Convention on the Rights of the Child. Florence: UNICEF Innocenti Research Centre.

UNICEF. (2006). The General Measures of the Convention on the Rights of the Child: The Process in Europe and Central Asia. Florence: UNICEF Innocenti Research Centre.

UNICEF. (2007a). Implementation Handbook for the Convention on the Rights of the Child. Third Edition. Geneva: UNICEF Regional Office for Europe.

UNICEF. (2007b). Law Reform and Implementation of the Convention on the Rights of the Child. Florence: UNICEF Innocenti Research Centre.

UNICEF. (2007c). Child poverty in perspective: An overview of child well-being in rich countries, Innocenti Report Card 7, Florence: UNICEF Innocenti Research Centre. 
UNICEF. (2010a). General Measures of Implementation Database. Geneva: UNICEF Intranet. Unpublished.

UNICEF. (2010b). Child Friendly Budgets for 2010 and Beyond: Toward Global Economic Recovery with a Human Face. Conference Synthesis Report. Retrieved from http://www.unicef.org/socialpolicy/files/Synthesis_Report_06.02.2010.pdf

UNICEF Canada. (2010). It's Time for a National Children's Commissioner for Canada. Toronto: UNICEF Canada. Retrieved from http://www.unicef.ca/sites/default/files/imce uploads/DISCOVER/OUR\%20WORK/AD VOCACY/DOMESTIC/GOVERNANCE/DOCS/Commission\%20booklet\%20English\% 20Final.pdf

UNICEF Canada. (2013). Child Rights Impact Assessment: Discussion Paper, Prepared to support participant dialogue in Bringing Children in from the Margins: Symposium on Child Rights Impact Assessment, 14-15 May, Ottawa, Canada. Retrieved from http://www.unicef.ca/sites/default/files/imce uploads/TAKE\%20ACTION/ADVOCATE/ DOCS/child_rights_impact_assessment_discussion_paper.pdf

United Nations. (1969). Vienna Convention on the Law of Treaties, UN Doc. A/CONF. 39/26, adopted 23 May 1969, entered into force 27 Jan. 1980.

United Nations. (1989). Convention on the Rights of the Child, Adopted and opened for signature, ratification and accession by General Assembly resolution 44/25 of 20 November 1989, entered into force 2 September 1990, in accordance with article 49.

United Nations. (1993). Principles relating to the status of national institutions for the promotion and protection of human rights (The Paris Principles), UN Doc. A/48/134, 20 December 1993. Retrieved from http://www2.ohchr.org/english/law/parisprinciples.htm 
United Nations. (1996). The High Commissioner for Human Rights: An Introduction. Geneva: United Nations.

United Nations. (2014). United Nations Treaty Collection: Chapter IV Human Rights, 11. Convention on the Rights of the Child, New York, 20 November 1989, Status as at: 2008-2014 05:03:00 EDT. Retrieved from https://treaties.un.org/Pages/ViewDetails.aspx?src=TREATY\&mtdsg_no=IV$11 \&$ chapter $=4 \&$ lang $=$ en

UN Committee on the Rights of the Child. (1995). Consideration of Reports Submitted by States Parties: Concluding observations: Canada, UN Doc. CRC/C/15/Add.37, 20 June 1995.

UN Committee on the Rights of the Child. (1996). General Guidelines Regarding the Form and Contents of Periodic Reports to Be Submitted by States Parties Under Article 44, Paragraph 1 (B), of the Convention, UN Doc. CRC/C/58, 20 November 1996.

UN Committee on the Rights of the Child. (2002). General Comment No 2.: The Role of Independent National Human Rights Institutions in the Promotion and Protection of the Rights of the Child (CRC/GC/2002/2), Office of the United Nations High Commissioner for Human Rights, Geneva, Retrieved from ww2.ohchr/English/bodies/crc/comments.htm

UN Committee on the Rights of the Child. (2003a). Concluding observations of the Committee on the Rights of the Child: Canada, UN Doc. CRC/C/15/Add.215. Office of the United Nations High Commissioner for Human Rights, Geneva.

UN Committee on the Rights of the Child. (2003b). General Comment No. 5: General measures of implementation of the Convention on the Rights of the Child (CRC/GC/2003/5), Office of the United Nations High Commissioner for Human Rights, Geneva, Retrieved from ww2.ohchr/English/bodies/crc/comments.htm. 
UN Committee on the Rights of the Child. (2012). Consideration of reports submitted by States parties under article 44 of the Convention - Concluding observations: Canada, UN Doc. CRC/C/CAN/CO/3-4, 5 October, http://www2.ohchr.org/english/bodies/crc/crcs61.htm.

Van Bueren, G. (2003). The constitutional rights of children, Amicus Curiae, 46, 27-32.

Vel, Benjamin et al. (2010). Together we can do better for Children of Seychelles. Seychelles Alternative Report to the United Nations Committee on the Rights of the Child. Accessed March 17, 2014 from: http://www.crin.org/docs/Seychelles_CCYN_CRC_Report.pdf

World Health Organization Regional Office for Europe. (2014). Key findings from the Health Behaviour in School-aged Children (HBSC) study: international report from the 2009/2010 survey. Retrieved from http://www.euro.who.int/en/health-topics/Lifestages/child-and-adolescent-health/publications/2012/key-findings-from-the-healthbehaviour-in-school-aged-children-hbsc-study-international-report-from-the-20092010survey 